\title{
The Analysis of Pork Content in Processed Beef Meatballs at Ketahun, North Bengkulu District Using Genetic Marker Mitochondrial DNA Cytochrome b
}

\author{
Sipriyadi $^{1, *}$ Hasriany Vellarenza ${ }^{2}$ Choirul Muslim ${ }^{1}$ \\ ${ }^{1}$ Department of Biology, Faculty of Mathematics and Science (FMIPA), University of Bengkulu, Bengkulu, \\ Indonesia \\ ${ }^{2}$ Undergraduate Student, Department of Biology, Faculty of Mathematics and Science (FMIPA), University of \\ Bengkulu, Bengkulu, Indonesia \\ *Corresponding author. Email: sipri_yadi@yahoo.co.id
}

\begin{abstract}
This research aims to analyze the content of pork in the sold meatballs in the North Bengkulu district. The study was conducted in December 2019-May 2020. Meatball samples were taken from 12 meatball merchant stalls in Ketahun, North Bengkulu district. DNA genome samples were isolated from the meatball using DNeasy guidelines and protocols ${ }^{\circledR}$ mericon ${ }^{\circledR}$ Food Qiagen Mini Kit. The Cyt b gene of mitochondrial DNA was amplified using forward universal primer, reverse cow primer, reverse pig primer, and reverse mixed primer PCR (Polymerase Chain Reaction) as much as 30 cycles. The amplification result was running on electrophoresis with agarose gel $1 \%$ and visualized with UV Transluminator Gel Document System Axygen. The data obtained were then analyzed. The DNA band of each sample was visualized on gel agarose compared to marker $1 \mathrm{~Kb}$ with a size of $398 \mathrm{bp}$ (pig content marker). The results of the study showed that there were five of twelve meatball samples were contaminated with pork, namely BU7, BU8, BU9, BU11, and BU12. The information of pork content on meatballs can be used as a determining material in food safety policy in Bengkulu Province.
\end{abstract}

Keywords: Cytochrome b, Ketahun, Meatballs, Pork Contamination

\section{INTRODUCTION}

In Indonesia, there are numerous cases of meals involving pork. Indonesia places a high value on safe and halal food products as one of the world's most populous Muslim countries. The guarantee of halal food product needs to be considered because it can bother consumers. The methods commonly used for its guarantee are protein and Deoxyribose Nucleic Acid (DNA) analysis. The analysis based on protein is quite difficult to do because protein always depends on the type of tissue of raw materials and it is sensitive to environmental treatment during analysis such as preparation, laboratory storage, heating and shaking treatment [1].
Molecular DNA technology can be used as an accurate alternative solution to ensure whether the food is contaminated with pork [2]. Amongst the methods, PCR procedure is potentially being applied to detect the content of pork in beef meatballs [3]. By utilizing specific information from DNA, it is possible to identify the type of meat contaminating in a food serving even in small amount with an accurate result, and even if the contaminant is in a raw material or has been through the heating process [4]. 


\section{MATERIALS AND METHODS}

\subsection{Sample Collection}

Meatball samples were collected randomly from twelve meatball shops in Ketahun District, North Bengkulu. The meatballs were brought to the Biotechnology Laboratory, University of Bengkulu to be processed to next steps.

\subsection{DNA Extraction}

Meatball samples were extracted according to the DNeasy Mericon Food Kit (Qiagen) procedure. We homogenized $2 \mathrm{~g}$ of sample in a $50 \mathrm{ml}$ centrifugation tube. Then $10 \mathrm{ml}$ Lysis Buffer and $25 \mu \mathrm{l}$ Proteinase K solutions were put onto the tube. The combination was threaded in a vortex and incubated for 30 minutes at $60^{\circ} \mathrm{C}$ with steady speed to ensure thorough conveyance and moistening of the sample tested. Following incubation, the sample was placed on ice and chilled to room temperature $\left(15-25^{\circ} \mathrm{C}\right)$. It was centrifuged for 5 minutes to precipitate it $(2500 \mathrm{x} \mathrm{g})$. The supernatant added with chloroform $(500 \mu \mathrm{l})$ and placed into $2 \mathrm{ml}$ of micro centrifugation tube. It mixed by vortex intensely for $15 \mathrm{~s}$ then centrifuged at $14,000 \mathrm{x} g$ for $15 \mathrm{~min} .350 \mu \mathrm{l}$ buffer PB was pipetted into new micro centrifugation tube and $350 \mu \mathrm{l}$ of the upper aqueous was melded conscientiously in vortex.

We put the solution into the spin column of QIAquick and transfered $2 \mathrm{ml}$ of it into the collection tube. The flow-through was thrown away after centrifugation at $17,900 \times \mathrm{g}$ for 1 minute. We used the same collection tube, and the spin column was filled with $500 \mu \mathrm{l}$ of Buffer AW2. It centrifuged again at $17,900 \mathrm{x} \mathrm{g}$ for $1 \mathrm{~min}$, then thrown away the flow-through, and with the same collection tube then centrifuged again at $17,900 \times \mathrm{g}$ for 1 min to dry the membrane. After transferring to a spin column $1.5 \mathrm{ml}$ or $2 \mathrm{ml}$ micro centrifugation tube (not supplied), 150 $\mu 1$ Buffer EB was snipped straight onto the membrane. It was incubated for 1 minute at ambient temperature $\left(15-25^{\circ} \mathrm{C}\right)$ before being centrifuged for 1 minute at $17,900 \mathrm{x} \mathrm{g}$ to extract the pure DNA.

\subsection{Amplification of $D N A$}

The primer used in this study was based on Novianty et al., (2017) [6]. Universal forward and reverse primer for Cow:

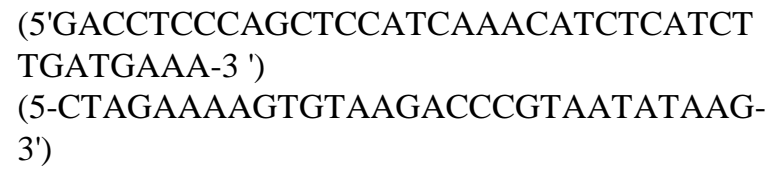

reverse primer for pork:

(5'-GCTGATAGTAGATTTGTGATGACCGTA-3 ') and reverse mixed primer (Cattle, Pigs, and Chickens) [6]. The overall volume of the reaction was $12.5 \mu \mathrm{l}$ which included $6.25 \mu \mathrm{l}$ Go Taq Green Mastermix, $0.5 \mu \mathrm{l}$ of each primer, $1 \mu \mathrm{l}$ DNA template, $4.25 \mu \mathrm{l}$ Nuclease Free Water. The amplification was performed under PCR conditions at pre-denaturation $\left(95^{\circ} \mathrm{C}, 3 \mathrm{~min}\right)$, denaturation $\left(95^{\circ} \mathrm{C}, 15 \mathrm{sec}\right)$, annealing $\left(60^{\circ} \mathrm{C}, 9 \mathrm{sec}\right)$, elongation $\left(72^{\circ} \mathrm{C}, 30 \mathrm{sec}\right)$, postextention $\left(72^{\circ} \mathrm{C}, 3 \mathrm{sec}\right)$, cooling $\left(15^{\circ} \mathrm{C}, 59 \mathrm{sec}\right)$, for denaturation, annealing, and elongation were repeated for 30 cycles.

\subsection{Visualization PCR Product with electrophoresis}

For 40 minutes, PCR products were running on a 1 percent agarose gel electrophoresis at 50 Volt. After soaking in Ethidium Bromide dye for 15 minutes and rinsing with distilled water for 1-5 minutes, the electrophoresis products were seen under UV light using Gel Document System Axygen.

\subsection{Data Analysis}

The results of the DNA band visualization were then quantified the amplicon size based on the markers. Analysis of amplification results based on the size of each DNA fragment or band was compared with the band position of the marker and positive control. Visualization of samples were identified as containing pork was shown with a band parallel to the positive control with a DNA fragment size around $398 \mathrm{bp}$.

\section{RESULT AND DISCUSSION}

The results showed that 12 samples from beef meatball shops contained a cow DNA band based on cow primer and mixed primer. Whereas samples with code BU 7, BU 8, BU 9, BU 10, BU 11, and BU 12 showed the presence of pork DNA bands in pork primers and mixed primers. Samples with code BU 4, BU 5, and BU 10 only showed the pig DNA band in the mixed primer, whereas in pork there was not amplified band as showed in Figure 3 and Figure 4. The contamination of pig's DNA in a product can be detected even though only in $1 \%$ amount. However, the sample cannot be set as positively contaminated with pig DNA because the bands appearing were very thin and they could be smears or scratches. 


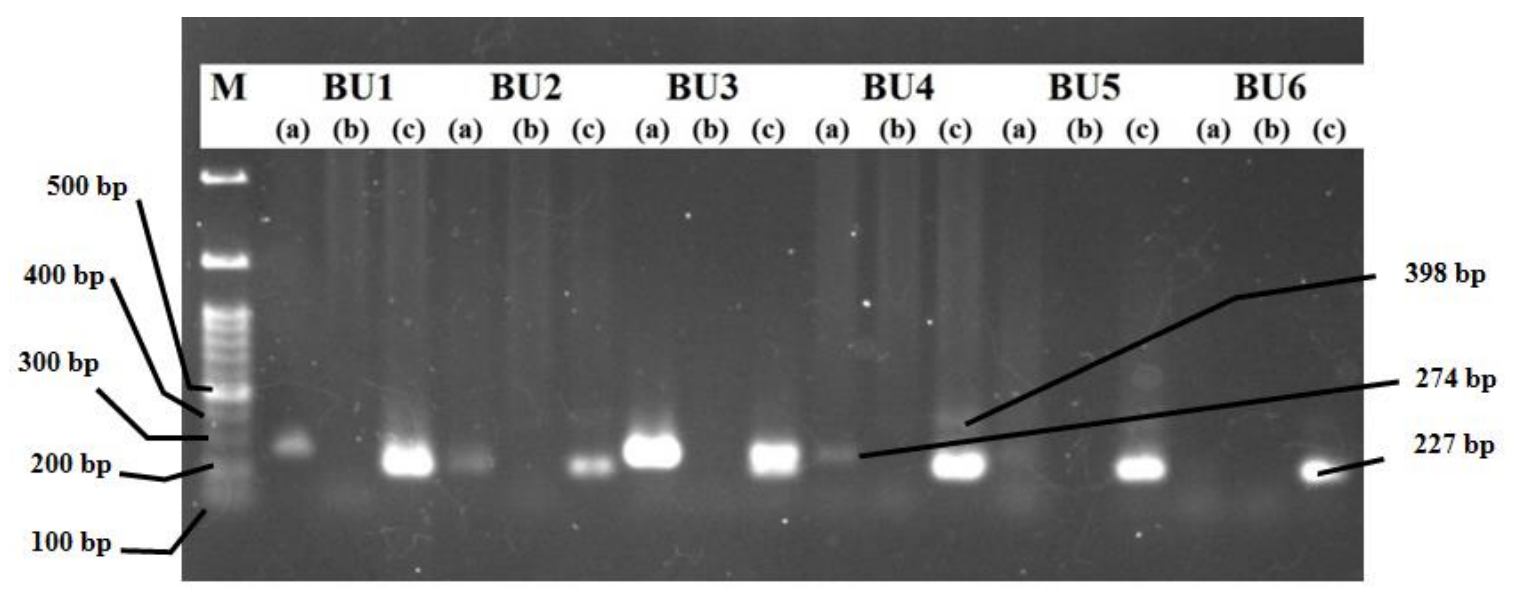

Figure 1. The result of PCR products visualization from meatball samples BU 1 to BU 6, (a) amplification using beef primer, (b) amplification using pig primers, (c) amplification using mixed primers (cow, pork, and chicken)

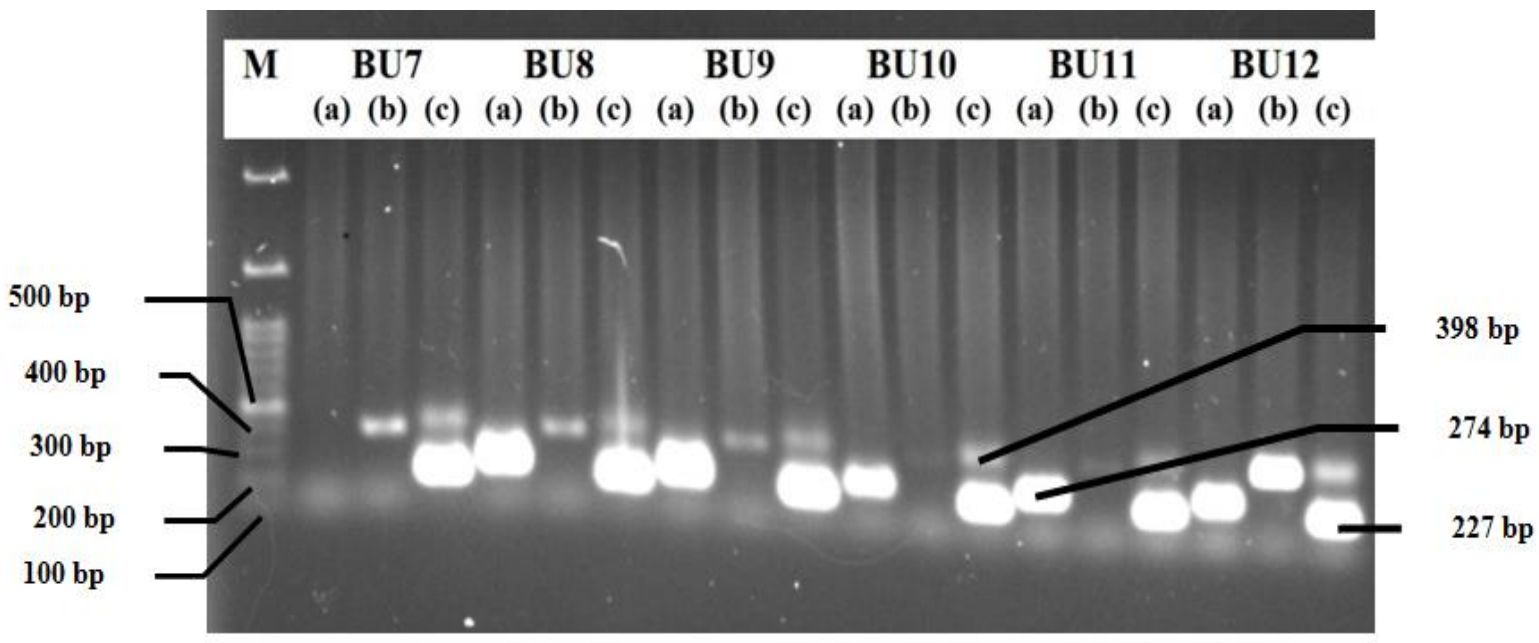

Figure 2. The result of PCR products visualization from meatball samples BU 7 to BU 12, (a) amplification using beef primer, (b) amplification using pig primers, (c) amplification using mixed primers (cow, pork, and chicken)

To assess the specificity of the cytochrome $b$ primers, mixed primers were employed in this study. Pork specific cytochrome $b$ primers have been designed and strengthened by Matsunaga et al. (1999) [7] using Multiplex PCR and yielded a band with 398 bp length. Primer design heavily influenced the success of PCR technique. Qualitative results for species identification generally showed by Conventional PCR techniques. So that, samples which showed pork DNA bands in the mixed primer did not show any bands on the pork primer. Primer is a strong indication to assume that sample is suspected of being contaminated with pork.

The heating process and physical treatment of meat products processes such as meatballs can reduce
The electrophoresis process was conducted using $1 \%$ agarose gel with ethidium bromide staining. There were several thick DNA bands and still visible scratches (smears) based on visualization result. Some factors like molecular size, agarose concentration, stress, and the type of electrophoretic buffer used can also affect the quality of the DNA bands. The agarose concentration utilized is determined by the size of the DNA fragment in the sample. The larger size of DNA sample fragment is the smaller agarose gel concentration used, and this study using $1 \%$ agarose gel concentration. The lower agarose concentration will generate the faster DNA fragments migration [8].

the quality of isolated DNA [9]. The results of meat isolation that had previously been treated using high 
temperatures show the smear band pattern on the electrophoresis gel which indicated the degradation of nucleic acids and it had a very low molecular weight when compared to DNA samples isolated from raw materials. DNA will also be degraded by heat treatment and radical action even it is more stable than protein [10]

We encountered the fact that PCR DNA bands result from the application of mixed primers was differed from thick to flimsy smear bands. This is probably due to the overlap of cow and chicken site. Larger molecules migrate slower than small molecules [11]. Cows (274 bp) and chickens (227 bp) have adjacent fragment lengths so that the migration rates are relatively same and produce overlapping bands. This DNA amplification process utilizes Cyt $b$ mitochondrial DNA (mtDNA) primers. The reason for using cytochrome $b$ primer as a marker in distinguishing material from different animal types is because there are sequence variations in cytochrome $\mathrm{b}$ which causing this gene can be widely used as a marker [12]. The use of a reverse mix primer was used to prove the specificity of the cytochrome $b$ primer used. Amplification of the cytochrome $b$ gene in this study resulted in fragments of $389 \mathrm{bp}$ for pigs, $274 \mathrm{bp}$ for cows, and $227 \mathrm{bp}$ for chickens. The amplicon of the cytochrome $b$ gene in this study is matched with Matsunaga et al. (1999) [7]. The specificity of the cytochrome $b$ gene sequence in each type of animal was shown by different lengths of fragment which indicated the cytochrome $b$ gene amplification was successfully done.

\section{CONCLUSION}

There were contaminations of pork DNA in meatball samples. Five of twelve samples were suspected of being contaminated with pork DNA. The samples are BU7, BU8, BU9, BU11, and BU12 which indicated by the presence of DNA band with 398 bp length.

\section{ACKNOWLEDGMENT}

This study was supported by Research and Community Services Centre (LPPM) University Of Bengkulu through 2019 Research Grant (Hibah Kerjasama Dalam Negeri Universitas Bengkulu) Grant number: 2187/ UN30.15 / LT / 2019 and all parties who have helped the completion of this research.

\section{REFERENCES}

[1] Undang-Undang Republik Indonesia Nomor 33 Tahun 2014 Tentang Jaminan Produk Halal [In Bahasa Indonesia]

[2] S.M. Ghovvati, Fraud Identification in Industrial Meat Product by Multiplex PCR assay. Food Control, 20(8) (2009), 696-699. DOI:10.1016/ j.foodcont.2008.09.002.

[3] S. R. Maryam, Determination of Porcine Contamination in Laboratory Prepared dendeng Using Mitochondrial DLoop686 and cytochrome b Gene Primers by Real-Time Polymerase Chain Reaction. International Journal of Food Properties, 19 (1) (2016), 187-195. DOI: 10.1080/10942912.2015.1020434.

[4] P. Husni, Metode Deteksi Kandungan Babi dan Alkohol dalam Eksipien Farmasi dan Produk Obat Untuk Menjamin Kehalalan Sediaan Obat. Majalah Farmasetika, 2 (1) (2017), 1-7. [In Bahasa Indonesia]

[5] C. Dewi, Aplikasi Pengggunaan Gen Sitokrom b dengan teknik Polymerase Chain Reaction (PCR) Sebagai Pendeteksi Campuran Daging. Skripsi, Bogor: Institut Pertanian Bogor (2011). [In Bahasa Indonesia]

[6] E. Novianty, L.R Kartikasari1, J.H, Lee, M, Cahyadi, Identification of pork contamination in meatball using genetic marker mitochondrial DNA cytochrome $b$ gene by duplex-PCR. IOP Conference Series: Materials Science and Engineering, 193(1) (2017), pp. 1-4. DOI: 10.1088/1757-899X/193/1/012002

[7] T. Matsunaga, K. Chikuni, R Tanabe, S. Muroya, K. Shibata, J. Yamada, Y. Shinmura, A Quick and Simple Method for the Identification of Meat Species and Meat Products by PCR Assay. Journal Meat Sciences, 51(2) (1999), 143-148. DOI: $10.1016 / \mathrm{s} 0309-1740(98) 00112-0$

[8] S. Magdeldin, Gel Electrophoresis Principles and Basics. Gel Electrophoresis-Principles and Basics. INTECH: University Campus STeP-Ri, China (2012) DOI: 10.5772/2205

[9] S. Andree, K. Altmann, R. Binke, F.Schwagele, Animal species identification and quantification in meat and meat products by means oftraditional of real-time PCR. Fleischwirtschaf, 85(1) (2004) 96-99. 
[10] I Martín, T García, V. Fajardo, M Rojas, P.E Hernández, I. González, R. Martín, Technical note: detection cat, dog, and rat or mouse tissues in food and animal feed using species-specific polymerase chain reaction. Journal Animal Science, 85(10) (2007) 2734-2739.

[11] J.R. Sambrook, Molecular Cloning a Laboratory Manual Ed 3rd. United State of America (US), COLD SPRING HARBOR LABORATORY PRESS: New York (2001)
[12] E. Vivikananda, Deteksi DNA Babi dan DNA Sapi dengan Menggunakan Metode Insulated Isothermal Polymerase Chain Reaction (iiPCR). Jakarta: UIN Syarif Hidayatullah. (2014). [In Bahasa Indonesia] 